\title{
Islamic Investment in Singapore
}

\author{
Haron Masagoes Hassan*
}

The financial market continues to give both positive and negative outlooks for 2017. The equity market in major developed regions is at an all-time high, with US stock leading the way. Nevertheless, and as is commonly known, financial institutions have cautioned investors with reports of market volatility, uncertainty and deteriorating corporate earnings.

But while the equity market seems to be experiencing a downturn, there is a positive outlook in Islamic finance. As reported by Standard \& Poor (S\&P) Islamic Finance Outlook 2017, Shariah compliant financial assets for this year are steadily growing to $\$ 3$ trillion from $\$ 2.1$ trillion at the end of 2016 as products expand in the Middle East, Southeast Asia, Africa and even America. Indeed, Islamic finance has expanded to many Western jurisdictions. In 2014 the United Kingdom (UK), for instance, became the first Muslim minority country to show interest in becoming a major player in Sukuk (Islamic bonds), a decision followed by Luxembourg, South Africa, Hong Kong and most recently Japan.

This positive outlook for the Islamic financial market rests on Islamic jurisprudence's efforts to standardise Shariah documents in order to unlock global potential. For instance, the issuance of a Shariah Standard for Gold Trading and Gold investment, in addition to trust and support from central governments, has served to build confidence. In this regard, Chart 1 illustrates the forecast for Islamic finance assets from the year 2009 to 2018. Another factor contributing to the flourishing of Islamic finance is the collaboration between Islamic finance players, investors and businesses. For example, the Islamic Bank of Turkey officially participates in activities and businesses that are socially responsible and ethically Shariah compliant. Consequently, the Islamic banking landscape in Turkey has outgrown the conventional system over the past 10 years, hovering around 5\% growth of market share in 2016. 


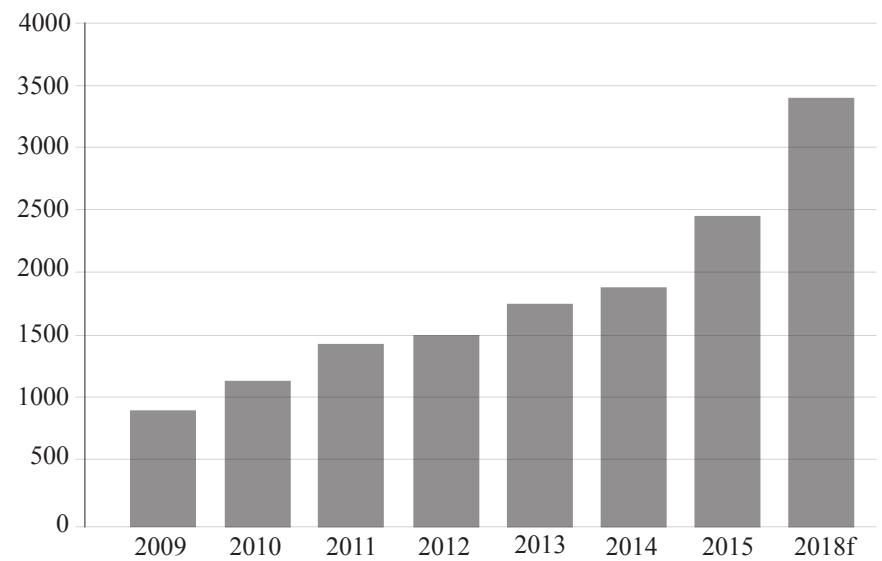

Chart 1: Total Islamic finance assets forecasted for year 2009 to 2018 and onwards.

(source: The International Shari'ah Research Academy for Islamic Finance, www.truewealthpublishing.asia)

Although the market for Islamic products in Singapore is small, demand from the country's minority Muslim population has been increasing year-on-year. They require Shariah compliant products that will fulfil their financial plans and livelihood needs while remaining free of riba (interest), gharar (uncertainty and lack of transparency) and masyir (gambling). An awareness campaign initiated by dedicated Muslim finance professionals has assisted these Muslims in creating demand for Shariah compliant investment portfolios. As the markets have grown, a wide range of asset classes and products have been introduced. With regards to investment portfolios, for example, Singaporean Muslims now have the ability to invest in the following asset classes: the global equity fund (Templeton Shariah Global Equity); the Asian equity fund (Templeton Shariah Asian Equity); the global sukuk fund (Templeton Global Sukuk); the global commodity fund (Deutsche Noor Precious Metals); Singapore REITS (Sabana REITS); and SGX shares that are screened by ideal ratings software.

Since the trend to invest in Islamic products has shown promising growth in Singapore, the following strategies for diversifying Islamic product portfolios may be useful. For 'moderate-risk' investors, financial experts can create a $60 \%$ equities $40 \%$ bonds portfolio. For example: $20 \%$ Global Equities; $20 \%$ Asian Equities; $10 \%$ Global Commodity; 10\% Singapore REITS or SGX shares; and $40 \%$ global sukuk. This strategy of combining equities and bonds will help investors maximise returns while minimising risk. For 'high risk' investors, on the other hand, $100 \%$ equity portfolios should be considered, for example: $20 \%$ 
Global Equities; 40\% Asian Equities; 20\% Global Commodities; 10\% Singapore REITS; and 10\% SGD shares. The key consideration here is that all equities be Shariah compliant.

Rating is very crucial for investors who choose investment portfolios, whether in Singapore or elsewhere. Being rated by reputable rating agencies, such as Standard and Poor Global Ratings or Morningstar, will enhance investor confidence in the products being offered. It allows investors to invest in Islamic products with confidence, as transparency is duly detailed. Recent history has proven that lack of transparency coupled with speculation in financial institutions leads to financial crisis and failure. A good example of this is the 2008 financial meltdown. In America, the root cause of this crisis was the repackaging of exotic products in conventional finance, such as undisclosed subprime instruments.

Though ratings are not the ultimate tool for building confidence (other factors include counter party risks and political risks), many Singaporean investors find they provide sufficient information concerning a portfolio. Table 1 shows how major sukuk issuers have gained traction in the international arena via that ratings. The table also shows that the Islamic Development Bank (IDB) and Government of Malaysia are among the most highly rated obligators.

\begin{tabular}{|c|c|c|c|c|c|c|}
\hline Obligor & Country & Sukuk/Trus Certificates & Sector & $\begin{array}{l}\text { Date of } \\
\text { Rating }\end{array}$ & $\begin{array}{l}\text { Issued } \\
\text { (\&-eq } \\
\mathrm{Mn})\end{array}$ & $\begin{array}{l}\text { LT FC } \\
\text { Rating }\end{array}$ \\
\hline Emirates of Ras Al Khaimah & UAE & RAK Capital & Gov. & 2008 & 500 & A \\
\hline State of Qatar & QAT & SoQ Sukuk A Q.S.C. & Gov. & 2011 & 2,000 & AA \\
\hline State of Qatar & QAT & SoQ Sukuk A Q.S.C. & Gov. & 2011 & 2,000 & AA \\
\hline Islamic Development Bank & Saudi A. & IDB Trust Services Ltd. & Gov. & 2011 & 7,291 & AAA \\
\hline Government of Malaysia & Malaysia & $\begin{array}{l}\text { Wakalah Global Sukuk } \\
\text { Series } 2\end{array}$ & Gov. & 2011 & 800 & A- \\
\hline Republic of Indonesia & Indonesia & $\begin{array}{l}\text { Perusahaan Penerbit SNSN } \\
\text { Indonesia II }\end{array}$ & Gov. & 2011 & 1,000 & $\mathrm{BB}+$ \\
\hline Central Bank of Bahrain & Bahrain & $\begin{array}{l}\text { CBB International Sukuk } \\
\text { Company (No. 3) }\end{array}$ & Gov. & 2011 & 750 & BB \\
\hline Abu Dhabi Commercial Bank & UAE & $\begin{array}{l}\text { ADCB Islamic Finance } \\
\text { (Cayman) Ltd. }\end{array}$ & FI & 2011 & 500 & A \\
\hline Banque Saudi Fransi & Saudi A. & BSF Sukuk Ltd. & FI & 2012 & 750 & $\mathrm{BBB}+$ \\
\hline Axiata Group Bhd & Malaysia & Axiata SPV2 Bhd. & Corp. & 2012 & 1,000 & BBB \\
\hline Majed Al Futtaim & UAE & MAF Sukuk Ltd. & Corp. & 2012 & 900 & $\mathrm{BBB}$ \\
\hline Saudi Electric Co. & Saudi A. & $\begin{array}{l}\text { Saudi Electricity Global } \\
\text { Sukuk Co. }\end{array}$ & Corp. & 2012 & 500 & A- \\
\hline Saudi Electric Co. & Saudi A. & $\begin{array}{l}\text { Saudi Electricity Global } \\
\text { Sukuk Co. }\end{array}$ & Corp. & 2012 & 1,250 & A- \\
\hline
\end{tabular}

Table 1: Sukuk currently rated by S\&P Global (source: S\&P Islamic Finance Outlook 2017 Edition) 
Although it is prudent to be rated by a reputable global rating agency, in certain circumstances, especially during the soft market epoch, being so might actually downgrade products, especially Sukuk.

Islamic finance is packaged with certain values, namely adherence to Shariah principles and observance of Islamic ethics and corporate standards. This means that Singapore's Shariah advisors must ensure that the Islamic products being offered provide equitable solutions for both sellers and buyers, financiers and borrowers, fund managers and investors. Other dimensions they need to focus on are protection of the environment and maintenance of social well-being. Unethical practices, such as the financing of mega businesses involved in deforestation for commercial interest or irresponsible banking, should be avoided. From the Shariah point of view, Singaporean Muslim and non-Muslim individuals, in addition to corporate entities, are highly encouraged to pursue profit maximisation via profitable economic activities. Islamic commercial activities based on ethical concepts like fair trade or profit and loss sharing would, if strictly applied, help society achieve well-being. Although in areas like governance, law and regulation industry players may have failed to offer a positive outlook, Islam continues to offer benign principles for our economy.

To conclude, Islamic finance is set to retain its economic hotspot during the upcoming decades as demand for Islamic financial products increases. As awareness concerning the need to conduct financial activities in compliance with Islamic principles (Muamalat) increases, both in Singapore and elsewhere, the need to provide more ideal Shariah compliant products will become more pressing among providers. Indeed, apart from education and health, this will mark one of the most rapidly growing areas impacting upon global Muslim wealth and status. With the latest development in fin-tech worldwide, the growth in demand for Shariah compliant products is expected to run speedily. Since many will turn to Islamic finance because it offers an alternative to the shortcomings of the current world economic system, considerable focus will be placed on its environmental dimensions, attitudes towards social responsibility, transparency, equitability, integrity and accountability. Since ethical behaviour is common to all nations worldwide, to gain more trust and confidence, whether from Muslim or nonMuslim investors, Singaporean Islamic investment must grow through ethical practices with clear cut profit returns for investors.

\section{Notes}

* Haron Masagoes Hassan is a Senior Executive, Wealth Management, at Financial Alliance, an independent financial advisory firm in Singapore. 